\title{
Glucocorticoids and 11/-HSD1 are major regulators of intramyocellular protein metabolism
}

\author{
Stuart A Morgan1,2, Zaki K Hassan-Smith1,2, Craig L Doig',2, Mark Sherlock1,2, \\ Paul M Stewart1,2,3 and Gareth G Lavery 1,2 \\ IInstitute of Metabolism and Systems Research, Institute of Biomedical Research, \\ University of Birmingham, Birmingham, UK \\ ${ }^{2}$ Centre for Endocrinology Diabetes and Metabolism, Birmingham Health Partners, \\ University of Birmingham, Birmingham, UK \\ 3School of Medicine, Worsley Building, University of Leeds, Leeds, UK
}

Correspondence should be addressed to S A Morgan

Email

xstatic000@hotmail.com

\begin{abstract}
The adverse metabolic effects of prescribed and endogenous glucocorticoid excess, 'Cushing's syndrome', create a significant health burden. While skeletal muscle atrophy and resultant myopathy is a clinical feature, the molecular mechanisms underpinning these changes are not fully defined. We have characterized the impact of glucocorticoids upon key metabolic pathways and processes regulating muscle size and mass including: protein synthesis, protein degradation, and myoblast proliferation in both murine $\mathrm{C} 2 \mathrm{C} 12$ and human primary myotube cultures. Furthermore, we have investigated the role of pre-receptor modulation of glucocorticoid availability by $11 \beta$-hydroxysteroid dehydrogenase type 1 (11 $\beta$-HSD1) in these processes. Corticosterone (CORT) decreased myotube area, decreased protein synthesis, and increased protein degradation in murine myotubes. This was supported by decreased mRNA expression of insulin-like growth factor (IGF1), decreased activating phosphorylation of mammalian target of rapamycin (mTOR), decreased phosphorylation of 4E binding protein 1 (4E-BP1), and increased mRNA expression of key atrophy markers including: atrogin-1, forkhead box O3a (FOXO3a), myostatin (MSTN), and muscle-ring finger protein-1 (MuRF1). These findings were endorsed in human primary myotubes, where cortisol also decreased protein synthesis and increased protein degradation. The effects of 11-dehydrocorticosterone (11DHC) (in murine myotubes) and cortisone (in human myotubes) on protein metabolism were indistinguishable from that of CORT/cortisol treatments. Selective $11 \beta$-HSD1 inhibition blocked the decrease in protein synthesis, increase in protein degradation, and reduction in myotube area induced by $11 \mathrm{DHC} / \mathrm{cortisone}$. Furthermore, CORT/cortisol, but not 11DHC/cortisone, decreased murine and human myoblast proliferative capacity. Glucocorticoids are potent regulators of skeletal muscle protein homeostasis and myoblast proliferation. Our data underscores the potential use of selective $11 \beta$-HSD 1 inhibitors to ameliorate muscle-wasting effects associated with glucocorticoid excess.
\end{abstract}




\section{Introduction}

The pathophysiological effects of glucocorticoids (GCs) are well described and impact upon almost all organ systems within the body. This is highlighted in patients with GC excess, Cushing's syndrome, characterized by central obesity, hypertension, skeletal myopathy, and insulin resistance. In addition, up to $2.5 \%$ of the population is taking prescribed GCs, and their side effects represent a considerable clinical burden (Wei et al. 2004, Hassan-Smith et al. 2012).

GC availability and action depend not only on circulating levels, but also on the tissue-specific intracellular metabolism by 11ß-hydroxysteroid dehydrogenases (11 $\beta$-HSDs) (Stewart \& Krozowski 1999). Skeletal muscle expresses 11ß-hydroxysteroid dehydrogenase type 1 (11ß-HSD1), which converts inactive 11-dehydrocorticosterone (11DHC) to active corticosterone (CORT) (cortisone and cortisol in humans, respectively) (Morgan et al. 2009). In contrast to $11 \beta$-HSD2, which plays no physiological role in this tissue, 11 -HSD1 has been shown to regulate both insulin sensitivity and lipid metabolism of skeletal muscle (Morgan et al. 2009, 2013). Furthermore, overexpression has been described in rodent and human models of type 2 diabetes and age-associated muscle weakness (Whorwood et al. 2002, Abdallah et al. 2005, Zhang et al. 2009, Kilgour et al . 2013, Hassan-Smith et al. 2015), and selective 11ß-HSD1 inhibitors have consistently demonstrated an ability to cause insulin sensitization in preclinical and clinical studies (Alberts et al. 2003, Bhat et al. 2008). We have recently shown that deletion of $11 \beta$-HSD1 in mice protects against the adverse side effects associated with both active and inactive circulatory GC excess, including skeletal myopathy; highlighting 11ß-HSD1 as a potential therapeutic target in the treatment of Cushing's syndrome (Morgan et al. 2014).

Muscle mass is tightly controlled through the regulation of protein metabolism, myoblast proliferation, and myocyte differentiation - all vital processes in the repair and maintenance of healthy muscle tissue. Mammalian target of rapamycin (mTOR) is a central regulator of protein synthesis, regulating numerous components including the initiation and elongation factors (Thoreen et al. 2012). The converse, protein degradation is regulated by components of the E3 ubiquitin proteosomal system (UPS), including muscle-ring finger protein-1 (MuRF1) and atrogin-1, both target cellular proteins to the proteasome for hydrolysis (Lecker et al. 2006).

It is well established that GCs drive muscle atrophy through modulation of protein metabolism
(McGrath \& Goldspink 1982, Savary et al. 1998, Biedasek et al. 2011). However, the precise molecular mechanisms underpinning GC action, and the role of pre-receptor GC metabolism by $11 \beta$-HSD 1 in the regulation of intramyocellular protein metabolism and myoblast proliferation have not been fully explored. Therefore, we have characterized the effects of both active and inactive GC treatment, as well as a selective 11 $\beta$-HSD1 inhibitor, on muscle myotube area, intramyocellular protein synthesis, protein degradation, and myoblast proliferation in a rodent skeletal muscle cell line and human primary muscle cultures.

\section{Research design and methods}

\section{Cell culture}

Murine C2C12 myoblasts (European Collection of Cell Cultures, Salisbury, UK) were grown in DMEM (PAA Laboratories, Somerset, UK) supplemented with $10 \%$ fetal bovine serum (FBS) $\left(37^{\circ} \mathrm{C}, 5 \% \mathrm{CO}_{2}\right)$. Cells were grown to $60-70 \%$ confluence before differentiation (initiated by replacing growth media with DMEM with $5 \%$ horse serum). After 8 days, myoblasts fuse to form multinucleated myotubes.

Primary human myoblasts were obtained from PromoCell (Heidelberg, Germany). Myoblasts were cultured to $80 \%$ confluence, as per the manufacturer's guidelines using the supplied media. Once confluent, growth media was changed to a chemically defined differentiation media (PromoCell) and cells differentiated for 8 days to form myotubes.

Before treatment, all cells were cultured for $4 \mathrm{~h}$ in serumfree medium without additives. Specific treatments (concentrations and duration) are described in the Results section. The selective 11ß-HSD1 inhibitor, PF-877423, was provided through material transfer agreements with Pfizer Global R\&D (La Jolla, CA, USA) and its detailed potency has been described previously (Bujalska et al. 2008). Sigma supplied all reagents unless otherwise stated. The number of replicates used in each experiment is shown in the figure legends.

\section{Measurement of myotube area}

Myotube cultures were photographed under a phase contrast microscope at $4 \times$ magnification following $24 \mathrm{~h}$ treatments. The areas were measured in a total of 40 myotubes from multiple random fields using Image software (NIH). The observer was blinded to the treatment information at the time of analysis.

Published by Bioscientifica Ltd 


\section{Measurement of protein degradation}

Rates of protein degradation were determined by measuring the release of trichloroacetic acid (TCA) and soluble radioactivity from cellular proteins pre-labeled with $\left[{ }^{3} \mathrm{H}\right]$ tyrosine, as described previously (Menconi et al. 2008). After completing differentiation, myotubes were labeled with $1.0 \mu \mathrm{Ci} / \mathrm{mL}$ of $\mathrm{L}-\left[3,5-{ }^{3} \mathrm{H}\right]$ tyrosine (PerkinElmer) for $48 \mathrm{~h}$ in DMEM containing 2\% FBS. Cells were then treated for $24 \mathrm{~h}$ with treatments in DMEM containing $2 \mathrm{mM}$ unlabeled tyrosine. The culture medium was then transferred into a microcentrifuge tube containing $100 \mu \mathrm{L}$ of bovine serum albumin $(10 \mathrm{mg} / \mathrm{mL})$, and TCA was added to a final concentration of $10 \%$ (wt/vol). Samples were incubated at $4^{\circ} \mathrm{C}$ for $1 \mathrm{~h}$, followed by centrifugation for $5 \mathrm{~min}$. The supernatant was used for determination of TCA-soluble radioactivity. The protein precipitates were dissolved with a tissue solubilizer (Solvable, PerkinElmer). Cell monolayers were washed with ice-cold phosphatebuffered saline (PBS) and solubilized with $0.5 \mathrm{M} \mathrm{NaOH}$ containing $0.1 \%$ Triton X-100. Radioactivity in the cell monolayer and TCA-soluble and -insoluble fractions were measured using a Packard TRI-CARB 1600 TR liquid scintillation analyzer (Perkin-Elmer). Protein degradation was expressed as the percentage protein degraded over the $24 \mathrm{~h}$ period and was calculated as 100 times the TCA-soluble radioactivity in the medium divided by the TCA-soluble plus the TCA-insoluble radioactivity in the medium plus the radioactivity in the cell layer.

\section{Measurement of protein synthesis}

Rates of protein synthesis were determined by measuring the $\left[{ }^{3} \mathrm{H}\right]$ tyrosine incorporated into cellular proteins, as described previously (Menconi et al. 2008). Differentiated myotubes were treated for $48 \mathrm{~h}$ with treatments. During the last hour of incubation, myotubes were incubated with $2.0 \mu \mathrm{Ci} / \mathrm{mL}$ of $\mathrm{L}-\left[3,5-{ }^{3} \mathrm{H}\right]$ tyrosine in DMEM containing $2 \%$ FBS and $200 \mathrm{mM}$ unlabeled tyrosine. After incubation, the medium was removed and the cell monolayers were harvested in 10\% TCA. The TCA-precipitated proteins were washed several times and then solubilized with $0.1 \mathrm{~N} \mathrm{NaOH}$ containing 1\% Triton X-100. Radioactivity and protein levels were measured in aliquots from the solubilized proteins.

\section{Proliferation assay}

Myoblast proliferation was assessed using the Celltiter 96 aqueous one solution cell proliferation assay kit
(Promega), which is a non-radioactive colorimetric method for determining the number of viable cells in culture. The assay is composed of a tetrazolium compound (3-(4,5-dimethylthiazol-2-yl)-5-(3-carboxymethoxyphenyl)2-(4-sulfophenyl)-H-tetrazolium, inner salt, MTS) and an electron-coupling reagent (phenazine methosulfate (PMS)). Myoblasts were trypsinized and counted, before seeding at a concentration of approximately 1000 cells per well in 96-well plates (final volume: $100 \mu \mathrm{L}$ ), and incubated at $37^{\circ} \mathrm{C}, 5 \% \mathrm{CO}_{2}$ for $24 \mathrm{~h}$. Treatments were added to the culture media and the cells were further incubated at $37^{\circ} \mathrm{C}, 5 \% \mathrm{CO}_{2}$ for $48 \mathrm{~h}$. The proliferation assay was subsequently performed according to the manufacturer's protocol. Incubation with IGF1, a known activator of myoblast proliferation (Milasincic et al. 1996), was used as a positive control in these experiments. Selected results generated using the above methodology were validated using a 5-bromo-2'-deoxyuridine (BrdU) Cell Proliferation Assay Kit (Cell Signaling). The assay was performed according to the manufacturer's protocol using similar seeding densities and conditions described above.

\section{1ß-HSD1 enzyme assays}

Briefly, intact cell monolayers were incubated for $2 \mathrm{~h}$ at $37^{\circ} \mathrm{C}$ with $100 \mathrm{nM} 11 \mathrm{DHC}$ and tracer amounts of $\left[{ }^{3} \mathrm{H}\right]-11 \mathrm{DHC}$ (synthesized in-house (Bujalska et al. 2002)). Steroids were then extracted from the culture media using dichloromethane, separated using a mobile phase consisting of ethanol and chloroform (8:92) by thin layer chromatography and scanned using a Bioscan 3000 image analyzer (Lablogic, Sheffield, UK). Protein levels were assayed using a commercially available kit (Bio-Rad), and activity expressed as pmol of CORT generated/mg of protein $/ \mathrm{h}$.

\section{RNA extraction and real-time PCR}

Total RNA was extracted from tissue and cells using the Tri-Reagent system. RNA integrity was assessed by electrophoresis on $1 \%$ agarose gel. Concentration was determined spectrophotometrically at an optical density of $(\mathrm{OD})_{260}$. In a $50 \mu \mathrm{L}$ volume, $500 \mathrm{ng}$ of total RNA were incubated with $250 \mu \mathrm{M}$ random hexamers, $500 \mu \mathrm{M}$ dNTPs, $20 \mathrm{U}$ RNase inhibitor, $63 \mathrm{U}$ multiscribe reverse transcriptase, $5.5 \mathrm{mM} \mathrm{MgCl}$ and $1 \times$ reaction buffer. The reverse transcription reaction was carried out at $25^{\circ} \mathrm{C}$ for $10 \mathrm{~min}, 48^{\circ} \mathrm{C}$ for $30 \mathrm{~min}$ before the reaction was terminated by heating to $95^{\circ} \mathrm{C}$ for $5 \mathrm{~min}$. mRNA levels were determined using an ABI 7500 sequence detection

Published by Bioscientifica Ltd 
system (Applied Biosystems). Reactions were performed in singleplex in $10 \mu \mathrm{L}$ volumes on 96-well plates in a reaction buffer containing $2 \times$ TaqMan Universal PCR Master Mix (Applied Biosystems). Primers and probes were supplied by Applied Biosystems as premade 'assay on demands'. All reactions were normalized against the housekeeping gene $18 \mathrm{~S}$ rRNA, provided as a pre-optimized control probe. All target genes were labeled with 6-carboxyfluorescein (6-FAM), and the reference gene with 2'-chloro-7'phenyl1,4-dichloro-6-carboxy-fluorescein (VIC). The reaction conditions were as follows: $95^{\circ} \mathrm{C}$ for $10 \mathrm{~min}$, then 40 cycles of $95^{\circ} \mathrm{C}$ for $15 \mathrm{~s}$, and $60^{\circ} \mathrm{C}$ for $1 \mathrm{~min}$. Data were obtained as $\mathrm{Ct}$ values $(\mathrm{Ct}=$ cycle number at which logarithmic PCR plots cross a calculated threshold line) and used to determine $\Delta \mathrm{Ct}$ values $(\Delta \mathrm{Ct}=(\mathrm{Ct}$ of the target gene) - (Ct of the reference gene)). Data were expressed as arbitrary units using the following transformation $\left(\operatorname{arbitrary}\right.$ units $\left.(\mathrm{AU})=1000 \times\left(2^{-\Delta \mathrm{ct}}\right)\right)$.

\section{Protein extraction and immunoblotting}

Monolayers of cells were placed on ice, washed with cold PBS, and then scraped into $100 \mu \mathrm{L}$ of radioimmunoprecipitation assay (RIPA) buffer. For both tissue and cultured cell homogenates, samples were incubated at $-80^{\circ} \mathrm{C}(10 \mathrm{~min})$ on ice $(30 \mathrm{~min})$, and centrifuged at $4^{\circ} \mathrm{C}(10 \mathrm{~min}, 10,000 \mathrm{~g})$. The supernatant was transferred to a fresh tube and total protein concentration was determined by a commercially available assay (Bio-Rad Laboratories). An amount of $30-40 \mu \mathrm{g}$ of protein was resolved on to an SDS-PAGE (acryl-amide percentage varied according to protein size). Proteins were transferred onto nitrocellulose membrane, Hybond ECL (GE Healthcare). Primary (anti-mTOR, anti-pSer2448 mTOR, anti-4E binding protein 1
(anti-4E-BP1), anti-pThr37/46 4E-BP1, and anti-MuRF1 were purchased from Cell Signaling) and secondary antibodies (Dako) were used at a dilution of 1/2000. Membranes were re-probed for $\beta$-actin or $\alpha$-tubulin and primary and secondary antibodies used at a dilution of 1/5000 (Abcam). Bands were visualized using ECL detection kit (GE Healthcare) and quantified using ImageJ software.

\section{Statistical analysis}

Statistical comparisons were performed using SigmaStat 3.1 (Systat Software, Inc., Point Richmond, CA, USA). Data are presented as mean \pm S.E.M. with statistical significance defined as $P<0.05$. One- or two-way ANOVA followed by Bonferroni's multiple comparison post hoc test was used to compare treatments. Statistical analysis on real-time PCR data was performed on $\Delta \mathrm{Ct}$ values and not fold-changes or AU.

\section{Results}

Rates of protein synthesis and protein degradation were assessed in $\mathrm{C} 2 \mathrm{C} 12$ myotubes by measuring $\left[{ }^{3} \mathrm{H}\right]$ tyrosine incorporation into cellular proteins and measuring TCA-soluble radioactivity released into the culture media from cellular proteins pre-labeling with $\left[{ }^{3} \mathrm{H}\right]$ tyrosine, respectively. CORT $(62.5-1000 \mathrm{nM}, 24 \mathrm{~h})$ dose dependently decreased protein synthesis (Fig. 1A), while concomitantly increased protein degradation (Fig. 1B).

Consistent with the functional data, both CORT and 11DHC treatment $(250 \mathrm{nM}, 24 \mathrm{~h})$ decreased $\mathrm{C} 2 \mathrm{C} 12$ myotube area (Fig. 1C and D). Importantly, the effects of 11DHC were blocked by co-incubation with the selective
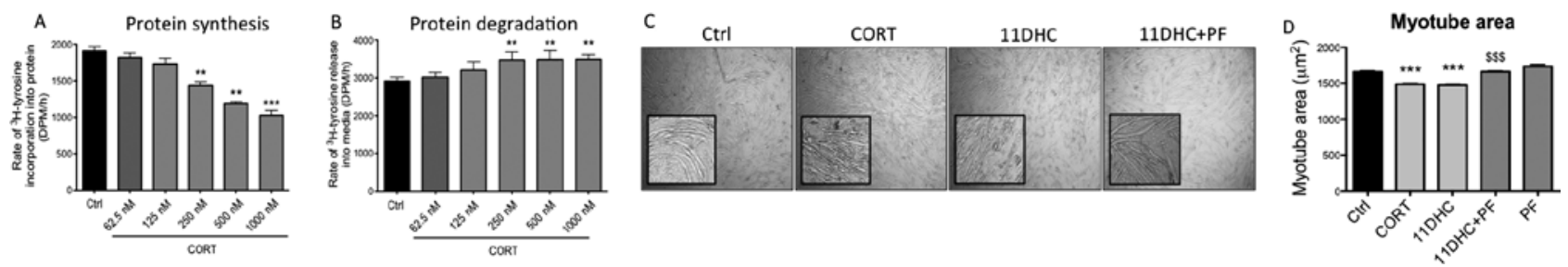

\section{Figure 1}

Treatment of C2C12 myotubes with corticosterone (CORT: $62.5-1000 \mathrm{nM}, 24 \mathrm{~h}$ ) decreased [3H]tyrosine incorporation into cellular proteins (protein synthesis). (A) Paralleled by increased TCA-soluble radioactivity released into media from cells pre-labeled with [ ${ }^{3} \mathrm{H}$ ]tyrosine (protein degradation). (B) Data analyzed using one-way ANOVA. C2C12 myotube area was decreased following treatment with CORT (250 nM, 24h) and 11-dehydrocorticosterone (11DHC, $250 \mathrm{nM}, 24 \mathrm{~h}$ ). (C) The selective 11 $\beta$-HSD1 inhibitor, PF-877423 (PF: $2.5 \mu \mathrm{M}, 24 \mathrm{~h})$, blocked the effects of 11DHC. Myotube area quantified from images using ImageJ software and analyzed using two-way ANOVA (C). Data expressed as mean \pm S.E.M. of $n=6$ experiments. ( $* * P<0.01, * * * P<0.001$ vs ctrl, $\$ \$ P<0.001$ vs $11 \mathrm{DHC}$ ). 
11 $\beta$-HSD1 inhibitor, PF-877423 (2.5 $\mu \mathrm{M}, 24 \mathrm{~h}$ ) (Fig. 1C and D). A concentration of $250 \mathrm{nM}$ was used, as this was the lowest concentration of CORT that resulted in statistically significant changes in rates of both protein synthesis and protein degradation.

Both CORT and 11DHC treatment (250nM, 24h) decreased $\left[{ }^{3} \mathrm{H}\right]$ tyrosine incorporation into cellular proteins (functional assessment of protein synthesis) in C2C12 myotubes (Fig. 2A), with the effects of 11DHC reversed by PF-877423 $(2.5 \mu \mathrm{M}, 24 \mathrm{~h})$. Gene expression analysis revealed decreased mRNA expression of insulin-like growth factor (IGF1) (a positive regulator of muscle size and mass) following both CORT and
11DHC treatment (Fig. 2B). By contrast, the mRNA expression of the following key genes regulating protein metabolism were unchanged: eukaryotic translation initiation factor 2B (Eif2B1) (a GDP exchange factor important for initiation of protein synthesis), eukaryotic translation initiation factor 4E-BP1 (a repressor of protein translation), mTOR (a serine/threonine kinase that senses nutritional/environmental cues and couples that signals to regulate protein metabolism), eukaryotic translation initiation factor 6 (EiF6) (forms a complex with $40 \mathrm{~s}$ ribosomal subunit involved in translation initiation), and histone acetyltransferase p300 (EP300) (a key activator of translation) (Fig. 2C, D, E, F and G). Consistent with

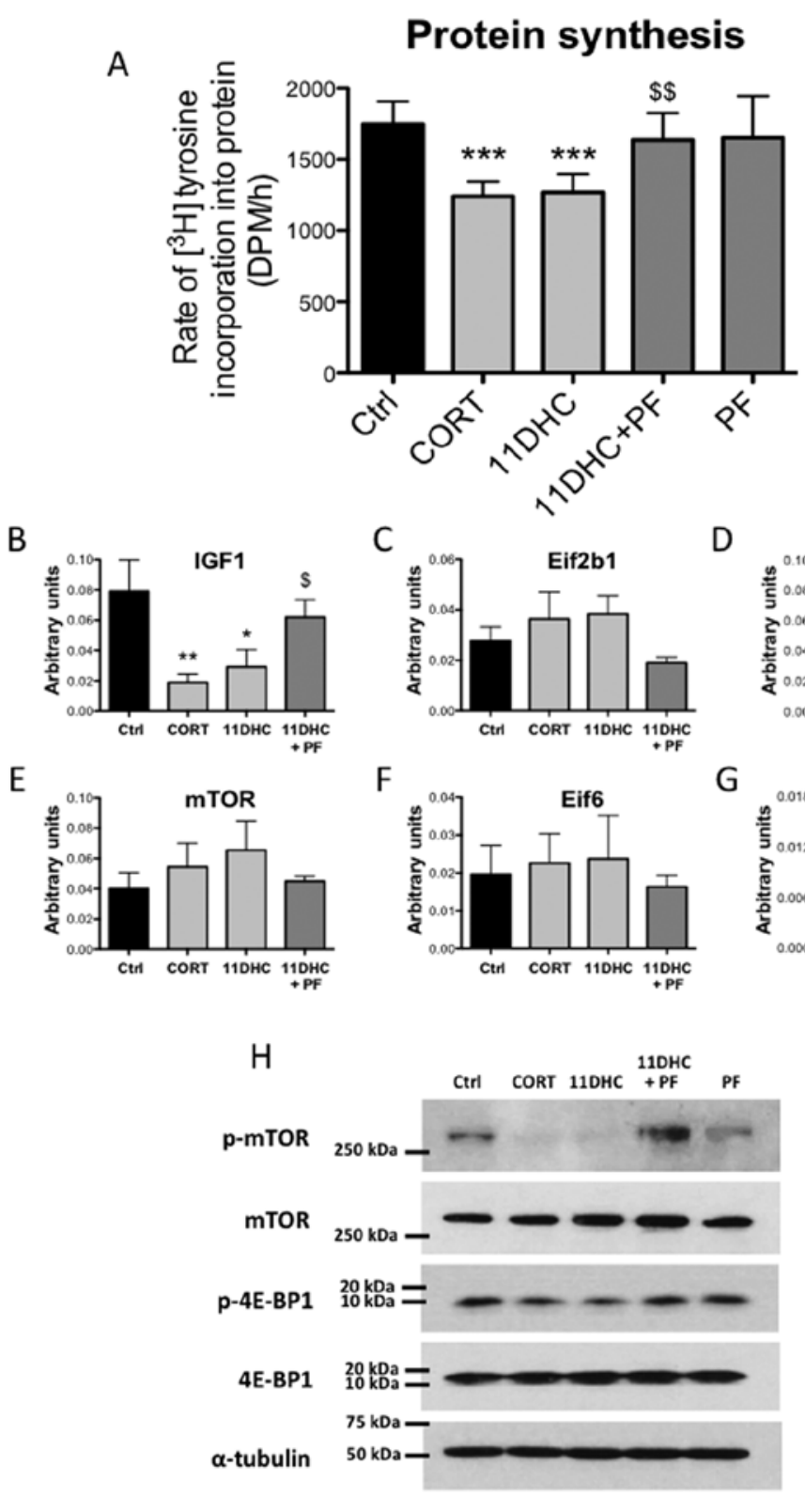

http://joe.endocrinology-journals.org DOI: 10.1530/JOE-16-0011
(C) 2016 Society for Endocrinology Printed in Great Britain
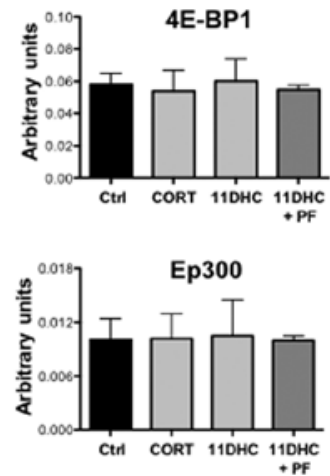

Figure 2

$\left[{ }^{3} \mathrm{H}\right]$ tyrosine incorporation into cellular proteins in C2C12 myotubes (protein synthesis) was decreased by both corticosterone (CORT: $250 \mathrm{nM}, 24 \mathrm{~h}$ ) and 11-dehydrocorticosterone (11DHC: $250 \mathrm{nM}, 24 \mathrm{~h}$ ). The selective 11 $\beta$-HSD1 inhibitor, PF-877423 (PF: $2.5 \mu \mathrm{M}, 24 \mathrm{~h}$ ), blocked the effects of 11DHC (A). Both CORT (250nM, 24h) and 11DHC ( $250 \mathrm{nM}, 24 \mathrm{~h})$ decreased IGF1 mRNA expression in $\mathrm{C} 2 \mathrm{C} 12$ myotubes (B), but Eif2b1 (C), 4E-BP1 (D), mTOR (E), Eif6 (F), and Ep300 (G) mRNA expression was unchanged. Serine-2448 phosphorylation of mTOR and threonine-37/46 phosphorylation of 4E-BP1 were decreased by both CORT $(250 \mathrm{nM}, 24 \mathrm{~h})$ and 11DHC (250 nM, 24h) in C2C12 myotubes, without effecting total protein levels. The effects of $11 \mathrm{DHC}$ on IGF1 expression, p-mTOR and p-4E-BP1 were reversed by PF-877423 (PF: $2.5 \mu \mathrm{M}, 24 \mathrm{~h})(\mathrm{B}$ and $\mathrm{H})$. Data expressed as mean \pm S.E.M. of $n=6$ experiments, and analyzed using two-way ANOVAs. Western blot analyses were carried out on at least three different preps. $\left({ }^{*} P<0.05, * * P<0.01\right.$, $* * * P<0.001$ vs ctrl, $\$ P<0.05, \$ \$ P<0.01$ vs $11 \mathrm{DHC})$. 
decreased protein synthesis, a trend toward decreased activating serine-2448 phosphorylation of mTOR and threonine-37/46 phosphorylation of 4E-BP1 was observed following CORT and 11DHC treatment, without effecting total protein levels (Fig. 2H). Importantly, PF-877423 reversed the effect of 11DHC on IGF1 mRNA expression, mTOR serine-2448 phosphorylation and 4E-BP1 threonine-37/46 phosphorylation (Fig. 2A, B and H). PF-877423 treatment alone $(2.5 \mu \mathrm{M}, 24 \mathrm{~h})$ was without effect on all parameters assessed.

Both CORT and 11DHC treatment $(250 \mathrm{nM}, 24 \mathrm{~h})$ increased the TCA-soluble radioactivity released into the culture media from $\mathrm{C} 2 \mathrm{C} 12$ myotube cellular proteins pre-labeled with $\left[{ }^{3} \mathrm{H}\right]$ tyrosine (functional assessment of protein degradation), with the effects of 11DHC reversed by PF-877423 $(2.5 \mu \mathrm{M}, 24 \mathrm{~h})$ (Fig. 3A). In agreement, the mRNA expression of key muscle atrophy markers including: atrogin-1, MuRF1 (both E3 ubiquitin ligases), myostatin (MSTN) (a negative regulator of muscle mass), and forkhead box O3a (FOXO3a) (a transcription factor that regulates muscle mass), as well as MuRF1 total protein levels, were increased by both CORT and 11DHC, with PF-877423 blocking the effects of 11DHC on all these readouts (Fig. 3B, C, D, E and F). PF-877423 treatment alone $(2.5 \mu \mathrm{M}, 24 \mathrm{~h})$ was without effect on all parameters assessed.

Myoblast proliferation is vital for the repair and maintenance of healthy muscle tissue. As such, we assessed the impact of both CORT and 11DHC on C2C12 myoblast proliferation (Fig. 4A). CORT (100-500 nM, 48 h) decreased myoblast proliferation in a concentrationdependent manner. This was consistent with CORTmediated decreased expression of IGF1 and myogenic factor 5 (MYF5) (both of which positively regulate myoblast proliferation) (Fig. 4B and C), whereas MSTN (a negative regulator of myoblast proliferation) expression was increased following CORT treatment (Fig. 4D). Importantly, we observed no difference in CASP3 or CASP7 expression (key apoptotic effectors) (Fig. 4E and F), suggesting that the observed CORT-mediated decrease in myoblast proliferation was not simply down to increased myoblast apoptosis.

In contrast to CORT, $11 \mathrm{DHC}(100-500 \mathrm{nM}, 48 \mathrm{~h})$ (which relies on activation to CORT by 11ß-HSD1) was without effect upon $\mathrm{C} 2 \mathrm{C} 12$ myoblast proliferation (Fig. 4A), consistent with the 30-fold lower 11ß-HSD1 oxoreductase activity (11DHC to CORT) in myoblasts compared with myotubes (Fig. $4 \mathrm{G}$ ). Incubation with IGF1 $(10 \mathrm{ng} / \mathrm{mL}, 48 \mathrm{~h})$, a known activator of myoblast proliferation, was used as a positive control in these experiments (Fig. 4A). The C2C12 myoblast proliferation data presented in Fig. 4 were measured using MTS and validated using BrdU (Supplementary Fig. 1, see section on supplementary data given at the end of this article).

To test whether these observations are relevant in a human setting, we treated human primary skeletal myotubes with cortisone $(250 \mathrm{nM}, 24 \mathrm{~h})$. Consistent with our findings in the $\mathrm{C} 2 \mathrm{C} 12 \mathrm{~s}$, cortisone decreased protein synthesis $\left(\left[{ }^{3} \mathrm{H}\right]\right.$ tyrosine incorporation into
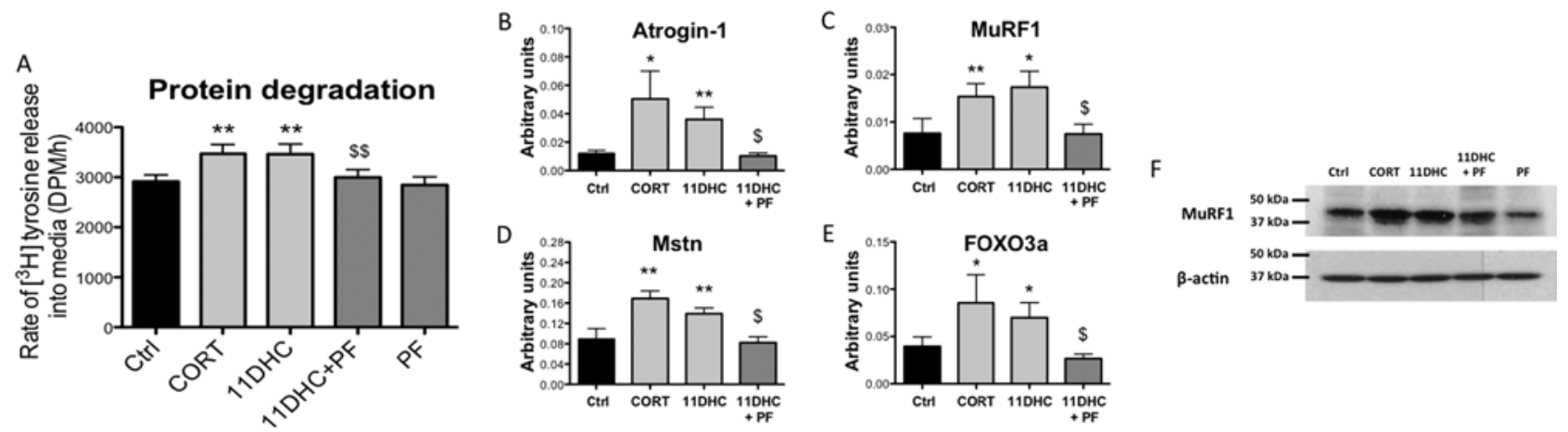

Figure 3

TCA-soluble radioactivity released into the culture media from $\mathrm{C} 2 \mathrm{C} 12$ myotubes pre-labeled with [ $\left.{ }^{3} \mathrm{H}\right]$ tyrosine was increased by both corticosterone (CORT: $250 \mathrm{nM}, 24 \mathrm{~h}$ ) and 11-dehydrocorticosterone (11DHC: $250 \mathrm{nM}, 24 \mathrm{~h}$ ). The selective $11 \beta$-HSD1 inhibitor, PF-877423 (PF: $2.5 \mu \mathrm{M}, 24 \mathrm{~h})$, blocked the effects of 11DHC (A). Both CORT ( $250 \mathrm{nM}, 24 \mathrm{~h})$ and 11DHC (250 nM, 24h) increased atrogin-1 (B), MuRF1 (C), Mstn (D), and FOXO3a (E) mRNA expression in C2C12 myotubes. Total protein levels of MuRF1 were also increased by both CORT and 11DHC (F). The effects of 11DHC on atrogin-1, MuRF1, Mstn, and FOXO3a mRNA expression as well as MuRF1 total protein levels was reversed by PF-877423 (PF: $2.5 \mu \mathrm{M}, 24 \mathrm{~h})$ (B, C, D, E and F). Data expressed as mean \pm S.E.M. of $n=6$ experiments, and analyzed using two-way ANOVAs. Western blot analyses were carried out on at least three different preps. ( ${ }^{*} P<0.05, * * P<0.01$ vs ctrl, $\$ P<0.01$ vs $11 \mathrm{DHC}$ ). 


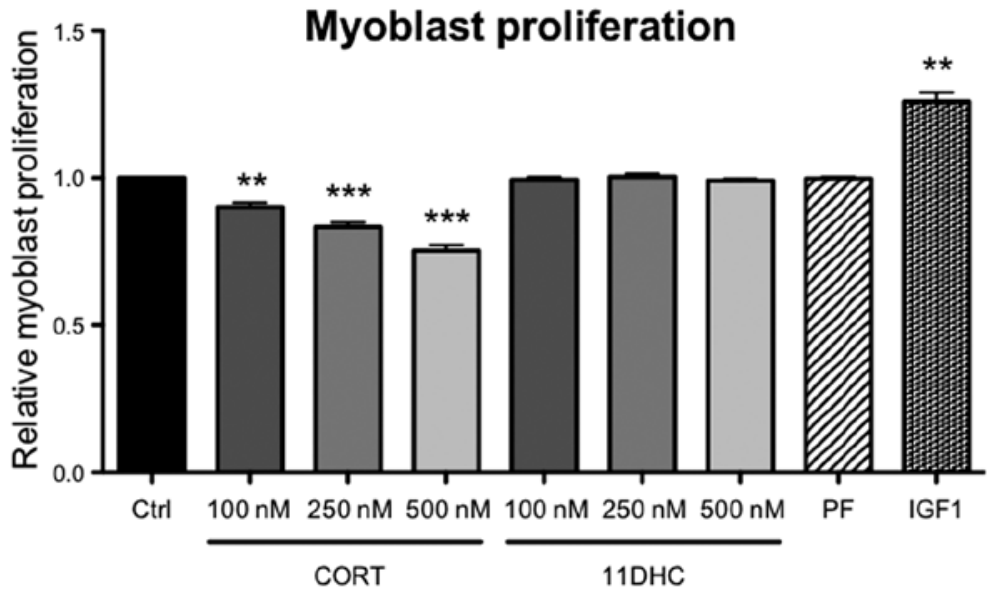

B

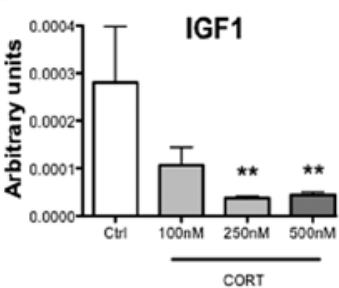

CORT

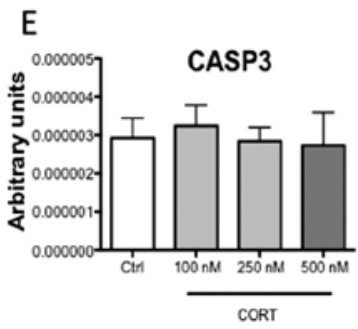

C

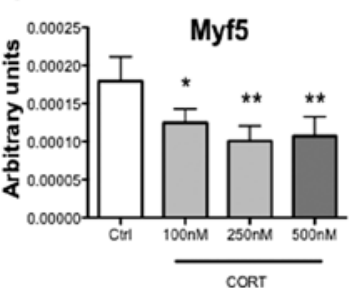

$\mathrm{F}$

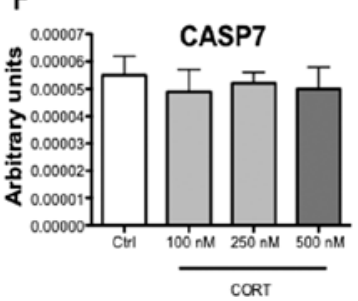

G
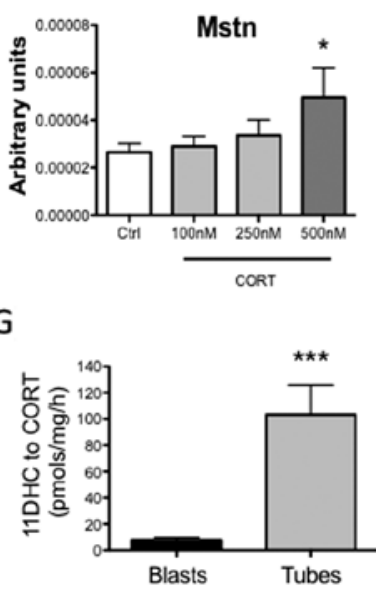

Figure 4

C2C12 myoblast proliferation was decreased by corticosterone (CORT: $100-500 \mathrm{nM}, 48 \mathrm{~h}$ ), but not 11-dehydrocorticosterone (11DHC: $100-500 \mathrm{nM}$, $48 \mathrm{~h}$ ), in a concentration-dependent manner (A). $\mathrm{C} 2 \mathrm{C} 12$ myoblasts treated with CORT $(100-500 \mathrm{nM}$, $24 \mathrm{~h}$ ) had deceased mRNA expression of IGF1 (B) and Myf5 (C), while Mstn expression was increased (D), whereas CORT was without effect on CASP3 (E) and CASP7 (F) expression. Low oxoreductase activity of $11 \beta-H S D 1$ (conversion of inactive 11DHC to active CORT) was detected in $\mathrm{C} 2 \mathrm{C} 12$ myoblasts, with activity increasing across myocyte differentiation (G). Data expressed as mean \pm S.E.M. of $n=6$ experiments, and analyzed using one-way ANOVAs. $\left({ }^{*} P<0.05, * * P<0.01, * * * P<0.001\right.$ vs (trl). cellular proteins) (Fig. 5A) and increased protein degradation (radioactivity release into the culture media from cellular proteins pre-labeled with $\left[{ }^{3} \mathrm{H}\right]$ tyrosine) (Fig. 5B). The effects of cortisol (250 nM, 24h) on protein synthesis and protein degradation in human primary myotubes were identical to that of cortisone (data not shown). Crucially, the effects of cortisone on protein synthesis and protein degradation were blocked by PF-877423 (2.5 $\mu \mathrm{M}, 24 \mathrm{~h})$ (Fig. 5A and B). In agreement with the $\mathrm{C} 2 \mathrm{C} 12$ data, cortisol (and not cortisone) was effective at suppressing myoblast proliferation (Fig. 5C).

\section{Discussion}

GC excess leads to skeletal muscle atrophy, however, the precise molecular mechanisms underpinning this observation is not completely understood. This has implications not only for the $1-2 \%$ of the population taking prescribed GCs (Wei et al. 2004), but also where elevated endogenous GC levels contribute to the muscle atrophy seen with starvation (Wing \& Goldberg 1993), sepsis (Tiao et al. 1996), and metabolic acidosis (May et al. 1986). Here, we have characterized the impact of GCs and pre-receptor GC metabolism upon intramyocellular protein metabolism and myoblast proliferation.

We have shown that GCs decrease the rate of protein synthesis in both mouse $\mathrm{C} 2 \mathrm{C} 12$ and human primary myotubes, in agreement with previously published reports (McGrath \& Goldspink 1982, Savary et al. 1998, Shah et al. 2000). Decreased activating serine-2448 phosphorylation of mTOR, a master regulator of protein metabolism, underpinned this finding. However, due to the vast number of environmental and nutritional cues that modulate mTOR activity, the mechanism(s) driving GC-mediated suppression of mTOR are likely to be complex (Laplante \& Sabatini 2012). Despite this, we did observe decreased IGF1 mRNA expression in C2C12 myotubes. IGF1 is synthesized and secreted by skeletal muscle and acts autocrine, paracrine, and endocrine to stimulate 
A

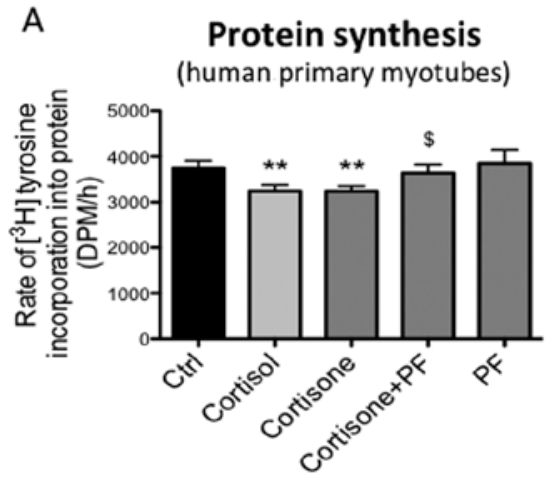

B

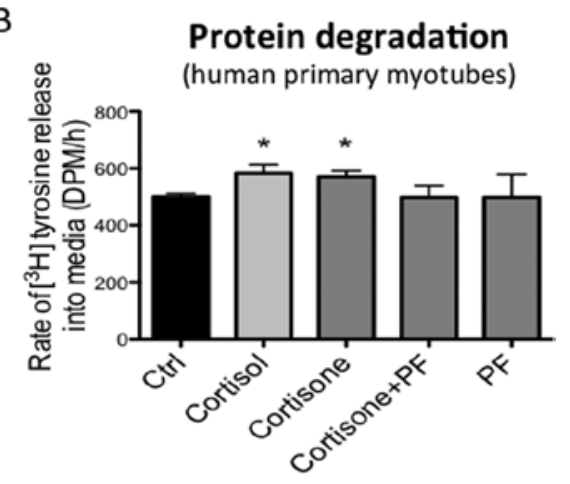

C

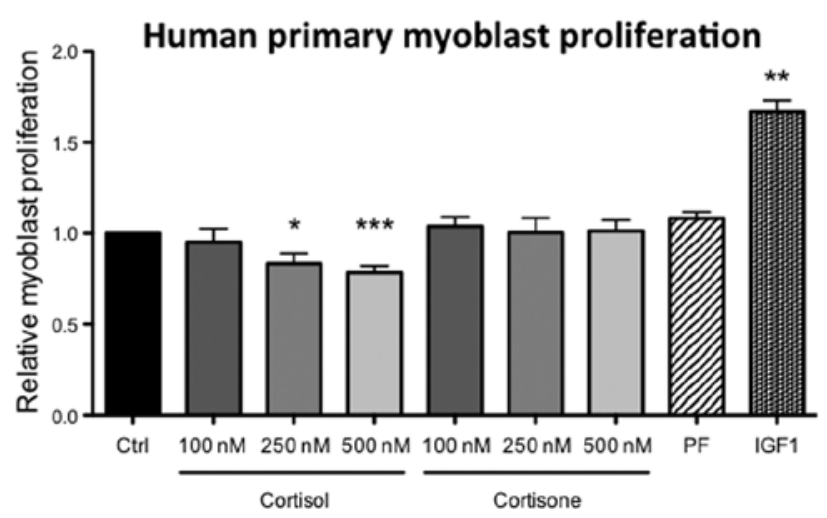

Figure 5

Treatment of differentiated human primary myotubes with cortisone ( $250 \mathrm{nM}, 24 \mathrm{~h}$ ) decreased [ $\left.{ }^{3} \mathrm{H}\right]$ tyrosine incorporation into cellular proteins (protein synthesis) (A), paralleled by increased TCA-soluble radioactivity released into the culture media from cells pre-labeled with $\left[{ }^{3} \mathrm{H}\right]$ tyrosine (protein degradation) (B). The selective 11 $\beta$-HSD1 inhibitor, PF-877423 (PF: $2.5 \mu \mathrm{M}, 24 \mathrm{~h}$ ), blocked the effects of cortisone on both protein synthesis and protein degradation. Proliferation of human primary myoblasts was decreased by cortisol (100-500 nM, 48h) in a concentration-dependent manner, but not cortisone (100-500 nM, 48h), (C). Data expressed as mean \pm S.E.M. of $n=6$ experiments, and analyzed using one- or two-way ANOVAs. $\left({ }^{*} P<0.05,{ }^{*} P<0.01, * * * P<0.001\right.$ vs ctrl, $\$ P<0.05$ vs cortisone).
mTOR, acting via AKT/PI3K pathway (Bodine et al. 2001, Rommel et al. 2001). Importantly, we have previously shown GCs to decrease insulin/IGF1-stimulated activation of AKT (Morgan et al. 2009), consistent with the observed reduction in mTOR serine- 2448 phosphorylation and suppressed protein synthesis reported here.

In agreement with attenuated protein synthesis, we observed a trend toward decreased 4E-BP1 threonine-37/46 phosphorylation following GC treatment. 4E-BP1 directly interacts with eukaryotic translation initiation factor $4 \mathrm{E}$ (eIF4E), which is a limiting component of the multisubunit complex that recruits $40 \mathrm{~S}$ ribosomal subunits to the $5^{\prime}$ end of mRNAs to be translated (Pause et al. 1994, Youtani et al. 2000). Phosphorylation at threonine-37/46 facilitates in its dissociation from eIF4E, allowing activation of mRNA translation. Interestingly, there is evidence that mTOR directly phosphorylates 4E-BP1 at threonine-37/46 (Gingras et al. 1999). As such, the observed decrease in mTOR activation following GC treatment could explain the hypophosphorylated state of 4E-BP1, keeping this suppressor of RNA translation firmly associated with eIF4E, thereby attenuating protein synthesis.

Concomitant with suppressed protein synthesis, GCs augmented protein degradation in both mouse C2C12 and human primary myotubes, consistent with previously published reports (McGrath \& Goldspink 1982,
Biedasek et al. 2011). This was underpinned by increased mRNA and protein expression of the key E3 ubiquitin ligases: MuRF1 and atrogin-1. In addition, the mRNA expression of MSTN, a known negative regulator of muscle size and mass, was decreased by GC treatment. Importantly, the GC-mediated decrease in protein synthesis and increased protein degraded resulted in decreased $\mathrm{C} 2 \mathrm{C} 12$ myotube area, consistent with the known muscle atrophying effects of GCs. Taken together, these data provide new mechanistic insight into the manner in which GCs mediate muscle-specific side effects associated with GC excess.

Previously, Biedasek and coworkers demonstrated that the non-selective HSD inhibitor, carbenoxolone, blocked cortisone-induced increase in protein degradation in human and murine myocytes induced by cortisone (Biedasek et al. 2011). In the current study, we have shown that the selective 11 $\beta$-HSD1 inhibitor, PF-877423, not only blocks 11DHC/cortisone-mediated increased protein degradation, but also 11DHC/cortisone-mediated suppression of protein synthesis in both $\mathrm{C} 2 \mathrm{C} 12$ and human primary myotubes. These findings were validated at a molecular level, where $11 \beta-H S D 1$ inhibition also blocked the gene expression changes and post-translational protein phosphorylation events mediated by 11DHC in C2C12 myotubes. As the net effect of these functional changes was to reverse

Published by Bioscientifica Ltd. 
11DHC-mediated C2C12 myotube atrophy, these results underscore the potential for a selective $11 \beta$-HSD1 inhibitor for the treatment of muscle atrophy induced by GC excess.

Regulation of muscle mass is not only governed by protein turnover, but also by myoblast proliferation is also a key factor in the repair and maintenance of healthy muscle tissue. Although previous studies have identified the highly potent synthetic GC, dexamethasone, to inhibit myoblast proliferation (te Pas et al. 2000, Dong et al. 2013), the impact of endogenous GCs, and the role of prereceptor GC metabolism by $11 \beta-H S D 1$ plays on myoblast proliferation has not been explored. In the present study, we found that active GCs (CORT/cortisol) to inhibit both rodent and human myoblast proliferative capacities, in agreement with the known effects of dexamethasone (te Pas et al. 2000, Dong et al. 2013). However, we found treatment with the inactive GCs (11DHC/cortisone) to be without effect upon myoblast proliferation, which a finding corroborated by 30-fold lower oxoreductase activity of 11ß-HSD1 (11DHC to CORT) in myoblasts compared with myotubes. As such, it is plausible that GCs reactivated by $11 \beta-H S D 1$ in mature myotubes regulate the proliferative capacity of undifferentiated myoblast pools located proximally in the muscle bed. This may represent an additional mechanism by which GCs and pre-receptor GC metabolism negatively regulate muscle mass.

Classical physiology studies have found transient GCs exposure to improve skeletal muscle performance (Schakman et al. 2009). These ergonomic effects are mediated by the induction of the metabolic transcription factor Krüppel-like factor 15 (KLF15) (Morrison-Nozik et al. 2015), defining a downstream pathway distinct from that resulting in GC-related muscle atrophy. These findings highlight the complex role GCs play in regulating of muscle physiology. Although, the transient effects of GCs have not been explored as part of the present study, investigation into the role of pre-receptor GC metabolism in the regulation of these ergogenic effects would be of great interest in future studies.

In conclusion, we have demonstrated that GCs are potent regulators of skeletal muscle protein homeostasis and myoblast proliferation. In addition, we have provided novel mechanistic insights into how GCs regulate these important metabolic pathways in vitro. Crucially, our data underscore the potential for the use of a selective $11 \beta$-HSD1 inhibitor to ameliorate musclewasting effects associated with GC excess in exogenous and endogenous Cushing's syndrome, starvation, sepsis, and metabolic acidosis.
Supplementary data

This is linked to the online version of the paper at http://dx.doi.org/10.1530/ JOE-16-0011.

\section{Declaration of interest}

The authors declare that there is no conflict of interest that could be perceived as prejudicing the impartiality of the research reported.

\section{Funding}

This work has been supported by the Biotechnology and Biomedical Sciences Research Council (ref. BB/G023468/1, (G G L); ref. BBB/S/M/2006/ 13045 (S A M)), ERC Advanced Research Grant (PRECORT) (P M S), Wellcome Trust Senor Research Fellowship (G G L) and a BMedSci final year project grant provided by the University of Birmingham.

\section{Author contribution statement}

$S A M, Z K H S$, and $C L D$ generated data for the manuscript. S A M, Z K H S, CLD, M S, P M S, and G G L all contributed to the writing of the manuscript. Study protocols were devised by $S A M, Z K H S$, and G G L. Project and hypothesis conceived by S A M and Z K H S.

\section{Acknowledgements}

The authors are grateful to Yasmine A Taher (Institute of Metabolism and Systems Research, University of Birmingham) for assistance in optimizing experimental protocols.

\section{References}

Abdallah BM, Beck-Nielsen H \& Gaster M 2005 Increased expression of 11 beta-hydroxysteroid dehydrogenase type 1 in type 2 diabetic myotubes. European Journal of Clinical Investigation 35 627-634. (doi:10.1111/j.1365-2362.2005.01552.x)

Alberts P, Nilsson C, Selen G, Engblom LO, Edling NH, Norling S, Klingstrom G, Larsson C, Forsgren M, Ashkzari M, et al. 2003 Selective inhibition of 11 beta-hydroxysteroid dehydrogenase type 1 improves hepatic insulin sensitivity in hyperglycemic mice strains. Endocrinology 144 4755-4762. (doi:10.1210/en.2003-0344)

Bhat BG, Hosea N, Fanjul A, Herrera J, Chapman J, Thalacker F, Stewart PM \& Rejto PA 2008 Demonstration of proof of mechanism and pharmacokinetics and pharmacodynamic relationship with 4'-cyano-biphenyl-4-sulfonic acid (6-amino-pyridin-2-yl)-amide (PF-915275), an inhibitor of 11-hydroxysteroid dehydrogenase type 1, in cynomolgus monkeys. Journal of Pharmacology and Experimental Therapeutics 324 299-305. (doi:10.1124/jpet.107.128280)

Biedasek K, Andres J, Mai K, Adams S, Spuler S, Fielitz J \& Spranger J 2011 Skeletal muscle 11beta-HSD1 controls glucocorticoid-induced proteolysis and expression of E3 ubiquitin ligases atrogin-1 and MuRF-1. PLOS ONE 6 e16674. (doi:10.1371/journal.pone.0016674)

Bodine SC, Stitt TN, Gonzalez M, Kline WO, Stover GL, Bauerlein R, Zlotchenko E, Scrimgeour A, Lawrence JC, Glass DJ, et al. 2001 Akt/ mTOR pathway is a crucial regulator of skeletal muscle hypertrophy and can prevent muscle atrophy in vivo. Nature Cell Biology 3 1014-1019. (doi:10.1038/ncb1101-1014)

Published by Bioscientifica Ltd 
Bujalska IJ, Walker EA, Tomlinson JW, Hewison M \& Stewart PM 2002 11Beta-hydroxysteroid dehydrogenase type 1 in differentiating omental human preadipocytes: from de-activation to generation of cortisol. Endocrine Research 28 449-461. (doi:10.1081/ERC120016822)

Bujalska IJ, Gathercole LL, Tomlinson JW, Darimont C, Ermolieff J, Fanjul AN, Rejto PA \& Stewart PM 2008 A novel selective 11betahydroxysteroid dehydrogenase type 1 inhibitor prevents human adipogenesis. Journal of Endocrinology 197 297-307. (doi:10.1677/ JOE-08-0050)

Dong Y, Pan JS \& Zhang L 2013 Myostatin suppression of Akirin1 mediates glucocorticoid-induced satellite cell dysfunction. PLOS ONE 8 e58554. (doi:10.1371/journal.pone.0058554)

Gingras AC, Gygi SP, Raught B, Polakiewicz RD, Abraham RT, Hoekstra MF, Aebersold R \& Sonenberg N 1999 Regulation of 4E-BP1 phosphorylation: a novel two-step mechanism. Genes and Development 13 1422-1437. (doi:10.1101/gad.13.11.1422)

Hassan-Smith ZK, Sherlock M, Reulen RC, Arlt W, Ayuk J, Toogood AA, Cooper MS, Johnson AP \& Stewart PM 2012 Outcome of Cushing's disease following transsphenoidal surgery in a single center over 20 years. Journal of Clinical Endocrinology and Metabolism 97 1194-1201. (doi:10.1210/jc.2011-2957)

Hassan-Smith ZK, Morgan SA, Sherlock M, Hughes B, Taylor AE, Lavery GG, Tomlinson JW \& Stewart PM 2015 Gender-specific differences in skeletal muscle 11beta-HSD1 expression across healthy aging. Journal of Clinical Endocrinology and Metabolism 100 2673-2681. (doi:10.1210/jc.2015-1516)

Kilgour AH, Gallagher IJ, MacLullich AM, Andrew R, Gray CD, Hyde P, Wackerhage H, Husi H, Ross JA, Starr JM, et al. 2013 Increased skeletal muscle 11betaHSD1 mRNA is associated with lower muscle strength in ageing. PLOS ONE 8 e84057. (doi:10.1371/journal.pone.0084057)

Laplante M \& Sabatini DM 2012 mTOR signaling in growth control and disease. Cell 149 274-293. (doi:10.1016/j.cell.2012.03.017)

Lecker SH, Goldberg AL \& Mitch WE 2006 Protein degradation by the ubiquitin-proteasome pathway in normal and disease states. Journal of the American Society of Nephrology 17 1807-1819. (doi:10.1681/ ASN.2006010083)

May RC, Kelly RA \& Mitch WE 1986 Metabolic acidosis stimulates protein degradation in rat muscle by a glucocorticoid-dependent mechanism. Journal of Clinical Investigation 77 614-621. (doi:10.1172/JCI112344)

McGrath JA \& Goldspink DF 1982 Glucocorticoid action on protein synthesis and protein breakdown in isolated skeletal muscles. Biochemical Journal 206 641-645. (doi:10.1042/bj2060641)

Menconi M, Gonnella P, Petkova V, Lecker S \& Hasselgren PO 2008 Dexamethasone and corticosterone induce similar, but not identical, muscle wasting responses in cultured $\mathrm{L} 6$ and $\mathrm{C} 2 \mathrm{C} 12$ myotubes. Journal of Cellular Biochemistry 105 353-364. (doi:10.1002/jcb.21833)

Milasincic DJ, Calera MR, Farmer SR \& Pilch PF 1996 Stimulation of C2C12 myoblast growth by basic fibroblast growth factor and insulinlike growth factor 1 can occur via mitogen-activated protein kinasedependent and -independent pathways. Molecular and Cellular Biology 16 5964-5973. (doi:10.1128/MCB.16.11.5964)

Morgan SA, Sherlock M, Gathercole LL, Lavery GG, Lenaghan C, Bujalska IJ, Laber D, Yu A, Convey G, Mayers R, et al. 2009 11beta-hydroxysteroid dehydrogenase type 1 regulates glucocorticoid-induced insulin resistance in skeletal muscle. Diabetes 58 2506-2515. (doi:10.2337/db09-0525)

Morgan SA, Gathercole LL, Simonet C, Hassan-Smith ZK, Bujalska I, Guest P, Abrahams L, Smith DM, Stewart PM, Lavery GG, et al. 2013 Regulation of lipid metabolism by glucocorticoids and 11beta-HSD1 in skeletal muscle. Endocrinology 154 2374-2384. (doi:10.1210/en.2012-2214)
Morgan SA, McCabe EL, Gathercole LL, Hassan-Smith ZK, Larner DP, Bujalska IJ, Stewart PM, Tomlinson JW \& Lavery GG 2014 11betaHSD1 is the major regulator of the tissue-specific effects of circulating glucocorticoid excess. PNAS 111 E2482-E2491. (doi:10.1073/ pnas.1323681111)

Morrison-Nozik A, Anand P, Zhu H, Duan Q, Sabeh M, Prosdocimo DA, Lemieux ME, Nordsborg N, Russell AP, MacRae CA, et al. 2015 Glucocorticoids enhance muscle endurance and ameliorate Duchenne muscular dystrophy through a defined metabolic program. PNAS 112 E6780-E6789. (doi:10.1073/pnas.1512968112)

Pause A, Belsham GJ, Gingras AC, Donze O, Lin TA, Lawrence JC Jr \& Sonenberg N 1994 Insulin-dependent stimulation of protein synthesis by phosphorylation of a regulator of 5'-cap function. Nature $\mathbf{3 7 1}$ 762-767. (doi:10.1038/371762a0)

Rommel C, Bodine SC, Clarke BA, Rossman R, Nunez L, Stitt TN, Yancopoulos GD \& Glass DJ 2001 Mediation of IGF-1-induced skeletal myotube hypertrophy by PI(3)K/Akt/mTOR and PI(3)K/Akt/GSK3 pathways. Nature Cell Biology 3 1009-1013. (doi:10.1038/ncb1101-1009)

Savary I, Debras E, Dardevet D, Sornet C, Capitan P, Prugnaud J, Mirand PP \& Grizard J 1998 Effect of glucocorticoid excess on skeletal muscle and heart protein synthesis in adult and old rats. British Journal of Nutrition 79 297-304. (doi:10.1079/BJN19980047)

Schakman O, Gilson H, Kalista S \& Thissen JP 2009 Mechanisms of muscle atrophy induced by glucocorticoids. Hormone Research $\mathbf{7 2}$ (Supplement 1) 36-41. (doi:10.1159/000229762)

Shah OJ, Kimball SR \& Jefferson LS 2000 Acute attenuation of translation initiation and protein synthesis by glucocorticoids in skeletal muscle. American Journal of Physiology: Endocrinology and Metabolism 278 E76-E82.

Stewart PM \& Krozowski ZS 199911 Beta-hydroxysteroid dehydrogenase. Vitamins and Hormones 57 249-324. (doi:10.1016/S00836729(08)60646-9)

te Pas MF, de Jong PR \& Verburg FJ 2000 Glucocorticoid inhibition of $\mathrm{C} 2 \mathrm{C} 12$ proliferation rate and differentiation capacity in relation to mRNA levels of the MRF gene family. Molecular Biology Reports 27 87-98.

Thoreen CC, Chantranupong L, Keys HR, Wang T, Gray NS \& Sabatini DM 2012 A unifying model for mTORC1-mediated regulation of mRNA translation. Nature 485 109-113. (doi:10.1038/nature11083)

Tiao G, Fagan J, Roegner V, Lieberman M, Wang JJ, Fischer JE \& Hasselgren PO 1996 Energy-ubiquitin-dependent muscle proteolysis during sepsis in rats is regulated by glucocorticoids. Journal of Clinical Investigation 97 339-348. (doi:10.1172/JCI118421)

Wei L, MacDonald TM \& Walker BR 2004 Taking glucocorticoids by prescription is associated with subsequent cardiovascular disease. Annals of Internal Medicine 141 764-770. (doi:10.7326/0003-4819-14110-200411160-00007)

Whorwood CB, Donovan SJ, Flanagan D, Phillips DI \& Byrne CD 2002 Increased glucocorticoid receptor expression in human skeletal muscle cells may contribute to the pathogenesis of the metabolic syndrome. Diabetes 51 1066-1075. (doi:10.2337/diabetes.51.4.1066)

Wing SS \& Goldberg AL 1993 Glucocorticoids activate the ATP-ubiquitindependent proteolytic system in skeletal muscle during fasting. American Journal of Physiology 264 E668-E676.

Youtani T, Tomoo K, Ishida T, Miyoshi H \& Miura K 2000 Regulation of human eIF4E by 4E-BP1: binding analysis using surface plasmon resonance. International Union of Biochemistry and Molecular Biology Life 49 27-31. (doi:10.1080/713803582)

Zhang M, Lv XY, Li J, Xu ZG \& Chen L 2009 Alteration of 11betahydroxysteroid dehydrogenase type 1 in skeletal muscle in a rat model of type 2 diabetes. Molecular and Cellular Biochemistry 324 147-155. (doi:10.1007/s11010-008-9993-0)

Received in final form 16 March 2016

Accepted 5 April 2016

Accepted Preprint published online 5 April 2016 http://joe.endocrinology-journals.org

DOI: 10.1530/JOE-16-0011
(C) 2016 Society for Endocrinology Printed in Great Britain
Published by Bioscientifica Ltd. 